\title{
Efektifitas Penggunaan Alat Peraga Sederhana untuk Meningkatkan Aktivitas Belajar Siswa
}

\author{
Baiq Yuni Wahyuningsih \\ Universitas Teknologi Mataram \\ baiquniq27@gmail.com
}

\begin{abstract}
This research was conducted to see how effective the use of media / teaching aids to improve student learning activities and outcomes in mathematics learning, especially in the ability to count addition and reduction of fractions. Learning activity intended here is how students can involve all aspects of psychophysics, both physical and spiritual so that accelerated changes in behavior can occur quickly, precisely, easily and correctly, both related to cognitive, affective and psychomotor aspects. This type of research is a classroom action research (CAR) which is part of an action research conducted by a teacher in class while teaching. This research uses a qualitative and quantitative approach. A qualitative approach was used to process data from observations of student and teacher activities. While the quantitative approach is used to process the test result data to determine student learning outcomes. This research was conducted in 2 (two) cycles. Each cycle consists of 3 times face to face. In general, each cycle starts from the action planning, the implementation stage of the action / implementation, observation and evaluation to the reflection stage. Based on the results of research and data analysis that has been done, it can be concluded that the use of teaching aids can increase student learning activities with a percentage in the first cycle of $1.34 \%$ and the second cycle of $3.33 \%$. Thus student learning activities in general have increased / increased by a percentage of 1.99\%. From the Fair category in Cycle I it becomes the Very High category after cycle II.
\end{abstract}

Keywords: Teaching Aids, Learning, Learning Activities

\begin{abstract}
Abstrak: Penelitian ini dilakukan untuk melihat bagaimana efektifitas penggunaan media/alat peraga untuk meningkatkan aktifitas dan hasil belajar siswa dalam pembelajaran matematika khususnya dalam kemampuan berhitung materi penjumlahan dan pengurangan pecahan. Aktifitas belajar yang dimaksudkan disini adalah bagaimana siswa dapat melibatkan seluruh aspek psikofisis, baik jasmani dan rohani sehingga akselerasi perubahan perilakunya dapat terjadi secara cepat, tepat, mudah dan benar, baik berkaitan dengan aspek kognitif, afektif dan psikomotor. Jenis penelitian yang digunakan adalah penelitian tindakan kelas (PTK) yang merupakan bagian dari penelitian tindakan (action research) yang dilakukan oleh guru dikelas pada saat mengajar. Penelitian ini menggunakan pendekatan kualitatif dan kuantitaif. Pendekatan kualitatif dilakukan untuk mengolah data hasil observasi aktivitas siswa
\end{abstract}

Islamika : Jurnal Keislaman dan Ilmu Pendidikan

Volume 2, Nomor 1, Januari 2020; 84-96

https:// ejournal.stitpn.ac.id/index.php/islamika 
dan guru. Sedangkan pendekatan kuantitatif dilakukan untuk mengolah data hasil tes untuk mengetahui hasil belajar siswa. Penelitian ini dilakukan dalam 2 (dua) siklus. Masing-masing siklus terdiri dari 3 kali tatap muka. Secara umum setiap siklus dimulai dari perencanaan tindakan, tahap pelaksanaan tindakan/implementasi, observasi dan evaluasi sampai tahap refleksi. Berdasarkan hasil penelitian dan analisis data yang telah dilakukan maka dapat diambil kesimpulan bahwa penggunaan alat peraga dapat meningkatkan aktivitas belajar siswa dengan persentase pada siklus I sebesar 1,34\% dan siklus II 3,33\%. Dengan demikian aktivitas belajar siswa secara umum mengalami kenaikan/peningkatan dengan persentase 1,99\%. Dari kategori Cukup pada Siklus I menjadi kategori Sangat Tinggi setelah dilaksanakan siklus II.

Kata Kunci: Alat Peraga, Belajar, Aktivitas Belajar

\section{PENDAHULUAN}

Dalam rangka meningkatkan mutu dan kualitas pendidikan, salah satu cara yang dapat ditempuh adalah dengan meningkatkan kualitas pembelajaran disetiap jenjang sekolah khususnya di jenjang sekolah dasar, sebab pada jenjang tersebut siswa diajarkan beberapa kemampuan dasar yaitu membaca, berhitung dan menulis. Hasil pembelajaran yang diperoleh siswa di sekolah dasar akan menjadi modal/kemampuan awal siswa dalam melanjutkan pendidikan/pembelajaran ke tingkat yang lebih tinggi. Sejauh ini pembelajaran yang menjadi momok yang menakutkan adalah matematika. Baik itu di jenjang SD, SMP, SMA bahkan pada jenjang perguruan tinggi. Hal ini terjadi karna sejak jenjang sekolah dasar siswa terpaku pada pembelajaran dengan metode ceramah sehingga kerap membuat siswa jenuh, tidak tertarik untuk memperhatikan dan cenderung mudah bosan.

Pembelajaran di jenjang sekolah dasar sebaiknya didasarkan atas pertimbangan bahwa secara psikologis siswa masih berada pada situasi "suka bermain". Oleh karena itu belajar yang didesain dengan konsep sambil bermain dapat membantu untuk menghilangkan kesan sulit dan kurang menyenangkan dalam belajar khususnya belajar matemtika. Dengan belajar sambil bermain siswa dapat mengkonstruk/membangun sendiri pengetahuannya melalui keaktifan dalam setiap proses belajarnya.

Sebagai ilmu pasti, matematika tidak pernah lepas dari kegiatan sehari-hari manusia, antara lain dalam perindustrian, perekonomian, pendidikan, bahkan dalam menentukan jatuhnya suatu hari tertentu, dapat dihitung menggunakan ilmu 
matematika. Oleh karena itu, penting sekali untuk menanamkan dasar-dasar ilmu matematika sejak awal pada peserta didik, seperti penambahan, pengurangan, perkalian dan pembagian. Dengan demikian, diharapkan pada akhirnya dapat membantu mempermudah peserta didik dalam memecahkan suatu masalah yang berkaitan dengan matematika dalam kehidupan sehari-hari.

Dengan demikian, pembelajaran matematika di jenjang sekolah dasar harus dibuat semenarik mungkin dan penyajiannya dengan cara-cara yang mudah dipahami untuk menarik minat dan motivasi belajar siswa. Keberhasilan pembelajaran matematika dapat dilihat dan diukur dari aktivitas kelas dan tingkat pemahaman serta penguasaan materi yang termuat dalam hasil belajarnya. Semakin tinggi tingkat pemahaman dan penguasaan materi makan akan semakin baik pula prestasi belajar yang dihasilkan. Namun daam kenyataannya prestasi belajar matematika yang dicapai oleh siswa masih sangat rendah. Selama ini pembelajaran yang berlangsung belum dapat meningkatkan keterampilan dasar siswa dalam behitung sehingga hal ini berdampak pada hasil belajarnya. Berdsarkan observasi yang telah dilakukan, terdapat permasalahan yang seringkali terjadi dalam pembelajaran matematika diantaranya yaitu: Kurangnya keterampilan berhitung siswa, ketidaksiapan siswa dalam menerima pelajaran/materi yang disampaikan, banyak siswa yang nilai matematikanya berada dibawah criteria ketuntasan minimum (KKM) dengan persentase ketuntasan klasikal sebesar 47,05\%, belum ditemukannya pembelajaran dengan menggunakan media/alat peraga yang sesuai dengan karakteristik siswa serta metode pembelajaran yang cenderung dilakukan secara konvensional.

Permasalahan yang diuraikan diatas kurang memberikan wadah bagi siswa untuk melibatkan diri secara aktif dalam menemukan konsep yang ingin disampaikan, padahal interaksi siswa dengan suatu media sangat diperlukan. Confusius ${ }^{1}$ menekankan pentingnya makna belajar dari pengalaman dengan menyatakan bahwa "saya dengar dan saya lupa", "saya lihat dan saya ingat", "saya lakukan dan saya paham". Dengan demikian betapa pentingnya makna proses "melakukan" untuk

\footnotetext{
${ }^{1}$ Ari Wibowo. “CONFUSIUS”. https://gendhonzz.wordpress.com/confusius/ diakses tanggal: 5 Januari 2020

${ }^{2}$ Mustaqim, Burhan. Ayu belajar matematika. Jakarta. Depatemen Pendidikan.
} 
memberikan kemudahan bagi siswa dalam kemampuan memahami dengan lebih baik sekaligus memunculkan aktifitas-aktifitas belajar siswa di kelas.

Berdasarkan permasalahan yang ada maka perlu dilakukan perbaharuan dalam pembelajaran untuk meningkatkan aktifitas dan hasil belajar siswa dalam hal kemampuan berhitung. Salah satu yang dapat dilakukan sebagai solusi dari permasalahan diatas adalah penerapan penggunaan media/alat peraga sederhana sesuai karekateristik siswa dalam pembelajaran berhitung. Kemudahan penggunaan alat peraga sederhana ini diharapkan dapat berdampak baik pada kecepatan dan ketepatan siswa dalam melakukan perhitungan. Dengan media/alat peraga pembelajaran akan menjadi lebih berkesan dan menarik sehingga diharapkan dapat meningkatkan aktivitas dan minat serta hasil belajar. Disisi lain suasana belajar akan menjadi lebih hidup, interaksi antara guru dan siswa dapat terjalin dengan baik yang akan meningkatkan keterampilan berhitung siswa.

Berdasarkan uraian latar belakang diatas maka penelitian ini dilakukan untuk melihat bagaimana efektifitas penggunaan media/alat peraga untuk meningkatkan aktifitas dan hasil belajar siswa dalam pembelajaran matematika khususnya dalam kemampuan berhitung materi penjumlahan dan pengurangan pecahan. Aktifitas belajar yang dimaksudkan disini adalah bagaimana siswa dapat melibatkan seluruh aspek psikofisis, baik jasmani dan rohani sehingga akselerasi perubahan perilakunya dapat terjadi secara cepat, tepat, mudah dan benar, baik berkaitan dengan aspek kognitif, afektif dan psikomotor. 


\section{METODE DAN PENDEKATAN PENELITIAN}

Jenis penelitian yang digunakan adalah penelitian tindakan kelas (PTK) yang merupakan bagian dari penelitian tindakan (action research) yang dilakukan oleh guru dikelas pada saat mengajar ${ }^{2}$ (Moleong 2010) yang bertujuan untuk memperbaiki dan meningkatkan kualitas dan kuantitas proses pembelajaran di kelas. Selanjutnya penelitian ini menggunakan pendekatan kualitatif dan kuantitaif. Pendekatan kualitatif dilakukan untuk mengolah data hasil observasi aktivitas siswa dan guru. Sedangkan pendekatan kuantitatif dilakukan untuk mengolah data hasil tes untuk mengetahui hasil belajar siswa.

Penelitian ini dilakukan dalam 2 (dua) siklus. Masing-masing siklus terdiri dari 3 kali tatap muka. Secara umum setiap siklus dimulai dari perencanaan tindakan, tahap pelaksanaan tindakan/implementasi, observasi dan evaluasi sampai tahap refleksi. Dalam tahap perencanaan tindakan, kegiatan yang dilakukan adalah membuat perangkat pembelajaran seperti Rencana Pelaksanaan Pembelajaran (RPP), Lembar Kerja Siswa (LKS), lembar observasi aktivitas guru dan aktivitas belajar siswa, alat evaluasi serta pedomannya dan membuat media/alat peraga, Tahap pelaksanaan tindakan merupakan pelaksanaan semua kegiatan yang telah direncanakan pada tahap perencanaan dan direalisasikan dalam kegiatan pembelajaran dikelas. Tahap selanjutnya yaitu observasi dan evaluasi. Observasi dilakukan oleh seorang pengamat saat proses pembelajaran berlangsung. Sedangkan evaluasi dilakukan dengan memberikan soal sebagai tes dengan skor per individu sesuai pedoman penskoran/penilaian. Tahap terakhir yaitu refleksi yang berisi kegiatan menganalisis, menjelaskan dan membuat kesimpulan berdasar pada data pengamatan yang diperoleh dari tahap observasi serta menghubungkannya dengan teori-teori yang digunakan. Hasil dari tahap refleksi selanjutnya dijadikan sebagai dasar untuk menyusun perencanaan tindakan pada siklus 2 dan seterusnya.

Instrumen penelitian yang digunakan berupa lembar observasi untuk mengamati aktivitas guru dan siswa saat belajar. Aktivitas siswa yang diamati berupa kesiapan mengikuti pembelajaran, antusias mengikuti pembelajaran/mengerjakan soal/menggunakan alat peraga/media dan partisipasi siswa dalam membantu

${ }^{3}$ Moleong, Lexy J. 2010. Metodologi Penelitian Kualitatif. Bandung: Remaja Rosdakarya. 
membuat kesimpulan hasil belajar. Sedangkan hal-hal yang diamati untuk aktivitas guru meliputi membuka dan mengakhiri pembelajaran, kemampuan menciptakan suasana kelas yang kondusif untuk belajar, kemampuan menggunakan media/alat peraga dalam menyampaikan materi. Teknik analisis data dilakukan secara deskriptif kualitatif. Aktivitas guru dan siswa dalam proses belajar akan dikategorikan dalam 5 kategori yaitu sangat baik, baik, cukup, kurang dan sangat kurang.

\section{HASIL DAN PEMBAHASAN \\ HASIL PENELITIAN}

\section{SIKLUS I}

1) Perencanaan

Pada tahapan ini dilakukan persiapan dan perencanaan pembelajaran meliputi alat dan bahan peraga serta perangkat pembalajaran yang akan digunakan, seperti: RPP, LKS, lembar observasi aktivitas belajar siswa dan guru, alat peraga/media dan perencanaan analisa hasil observasi dan evaluasi.

2) Pelaksanaan Tindakan

Proses pembelajaran berlangsung dalam dua kali tatap muka dengan lama 2 × 35 menit dan 1 kali tatap muka dipergunakan untuk melakukan evaluasi selama 1 x 35 menit. Pada saat pertemuan pertama dilaksanakan, guru memberikan pengenalan alat peraga serta bagaimana cara penggunaannya pada operasi penjumlahan pecahan dimulai dari pecahan yang sederhana. Ketika proses pembelajaran berlangsung tampak siswa masih cenderung kakau karena baru pertama kali menggunakan alat peraga tersebut sehingga belum mampu untuk terbiasa menghitung penjumlahan pecahan. Siswa masih terpaku pada aturan/teknik/cara berhitung yang pernah disampaikan sebelumnya. Dari segi aktivitas siswa terlihat sebagian besar siswa masih merasa takut untuk bertanya walaupun pada dasarnya belum sepenuhnya mereka dapat memahami. Ketika diberikan pertanyaan oleh guru, siswa banyak yang raguragu untuk menjawab dan belum menunjukkan keseriusan dalam mengerjakan tugas yang diberikan. Dengan demikian terlihat bahwa pada saat pertemuan pertama proses pembelajaran belum kondusif. Oleh sebab itu guru berusaha memberikan motivasi dengan cara memberikan bimbingan dan latihan dengan berkeliling kesetiap 
kelompok untuk mendemonstrasikan cara menghitung penjumlahan pecahan dengan menggunakan alat peraga.

Pada pertemuan kedua siswa sudah terihat lebih aktif dan terampil dalam menggunakan alat peraga untuk menghitung pengurangan pecahan. Hal ini terlihat dari semakin banyak siswa yang antusias dalam menjawab pertanyaan yang dijaukan oleh guru, sehingga suasa pembelajaran sudah mulai menjadi lebih kondusif. Meski demikian, dari 32 siswa ada beberapa siswa yang masih belum mengerti bagaimana cara menggunakan alat peraga untuk berhitung. Untuk mengatasinya guru mencoba memberikan bilbingan kembali khusus untuk siswa yang belum bisa sama sekali. Dalam membantu siswa untuk memhami konsep yang disampaikan, guru menempelkan konsep-konsep tersebut di dalam kelas dengan maksud agar siswa dapat mencoba praktek/latihan berhitung walaupun diluar jam pembelajaran matematika.

3) Observasi

Pada tahapan Observasi tindakan, berikut adalah hasil yang diperoleh:

Hasil Observasi Aktivitas Belajar Siswa

\begin{tabular}{|l|l|l|}
\hline Pertemuan & 1 & 2 \\
\hline Skor & 12,32 & 13,66 \\
\hline Kategori & Cukup & Cukup \\
\hline
\end{tabular}

Berdasarkan tabel diatas terlihat bahwa selama proses pembelajaran aktivitas berlajar siswa sudah terlaksana dengan baik. Hal ini ditunjukkan dari tingkat keiapan siswa dalam menerima dan mengikuti pembelajaran serta aktivitas dan interaksi siswa selama melakukan diskusi kelompok.

\section{Hasil Observasi Aktivitas Guru}

\begin{tabular}{|l|l|l|}
\hline Pertemuan & 1 & 2 \\
\hline Skor & 3,67 & 3,83 \\
\hline Kategori & Baik & Baik \\
\hline
\end{tabular}

Berdasarkan tabel terlihat bahwa aktivitas guru selama proses pembelajaran dalam kategori baik. Guru mampu menyampaikan materi pelajaran dengan baik dan mampu 
melakukan pembimbingan dan pelatihan secara terampil dalam menggunakan alat peraga untuk menghitung operasi penjumlahan dan pengurangan pecahan kepada siswa.

4) Refleksi

Pada tahap ini dilakukan refleksi terhadap kekurangan yang terjadi berdasarkan analisis hasil observasi. Pada aktivitas belajar siswa ditemukan kekurangan seperti, siswa belum memiliki keberanian untuk maju ke depan kelas untuk praktek menggunakan alat peraga, siswa masih ragu-ragu untuk bertanya dan atau mengungkapkan pendapat/gagasannya didepan kelas, siswa tidak membuat ringkasan materi. Sementara itu, untuk aktivitas guru, kekurangan yang ditemukan adalah guru belum dapat membagi waktu secara tepat sehingga belum semua siswa berkesempatan untuk mendemosntrasikan hasil tugas mereka dan masih ada hal-hal lain yang mengganggu proses belajar mengajar.

Berdasarkan kekurangan-kekurangan yang ditemukan, maka hal-hal yang perlu dilakukan sebagai upaya perbaikan adalah seperti guru harus membuat pembagian waktu dan penyusunan materi secara tepat agar siswa dapat mendemnatrasikan hasil tugas/diskusi yang telah dilakukan didepan kelas, dalam proses pembelajaran guru harus memberikan pertanyaan yang menarik agar dapat memotivasi siswa untuk menjawab atau bertanya kembali, guru sebaiknya dapat meningkatkan suasana belajar agar lebih kondusif agar siswa dapat rileks dan nyaman belajar sehingga memunculkan keberanian siswa.

\section{SIKLUS II}

1) Perencanaan

Pada tahapan ini dilakukan persiapan dan perencanaan pembelajaran meliputi alat dan bahan peraga serta perangkat pembalajaran yang akan digunakan, seperti: RPP yang disesuaikan dengan alat peraga yang digunakan, LKS, lembar observasi aktivitas belajar siswa dan guru, dan perencanaan analisa hasil observasi dan evaluasi.

2) Pelaksanaan Tindakan

Proses pembelajaran berlangsung dalam dua kali tatap muka dengan lama 2 x 35 menit dan 1 kali tatap muka dipergunakan untuk melakukan evaluasi selama 1 x 35 menit. Pada pertemuan pertama siswa diajarkan untuk melakukan operasi penjumlahan pada pecahan yang tidak senilai/senama. Guru berusaha menciptakan 
suasana belajar yang lebih kondusif dengan cara membuat pembelajaran menarik dengan menyertakan potongan-potongan gambar dan cerita pada saat menyampaikan materi/konsep. Selain itu guru mencoba memberikan motivasi kepada siswa untuk lebih berani mencoba walaupun belum sepenuhnya bisa dan menghilangkan keraguan dalam bertanya atau menjawab.

Pada pertemuan selanjutnya guru mengajak siswa untuk melakukan operasi pengurangan pada pecahan yang tedak senilai/senama. Di pertemuan ini guru memberikan LKS kepada siswa dengan tujuan memberikan kesempatan yang lebih banyak pada siswa untuk mencoba menyelesaikan soal didepan kelas dengan bantuan alat peraga yang ada.

3) Observasi

Pada tahapan Observasi tindakan, berikut adalah hasil yang diperoleh:

Hasil Observasi Aktivitas Belajar Siswa

\begin{tabular}{|l|l|l|}
\hline Pertemuan & 1 & 2 \\
\hline Skor & 17,67 & 21 \\
\hline Kategori & Tinggi & Sangat Tinggi \\
\hline
\end{tabular}

Berdasarkan tabel diatas terlihat bahwa selama proses pembelajaran aktivitas berlajar siswa sudah terlaksana dengan baik dalam kategori tinggi. Hal ini ditunjukkan dari tingkat kesiapan siswa dalam menerima dan mengikuti pembelajaran serta aktivitas dan interaksi siswa selama melakukan diskusi kelompok, keberanian siswa dalam menjawab atau memberikan pertanyaan, serta mempraktekkan penggunaan alat peraga didepan kelas.

\section{Hasil Observasi Aktivitas Guru}

\begin{tabular}{|l|l|l|}
\hline Pertemuan & 1 & 2 \\
\hline Skor & 4 & 4,17 \\
\hline Kategori & Sangat Baik & Sangat Baik \\
\hline
\end{tabular}

Berdasarkan tabel hasil observasi diatas, terlihat bahwa guru sudah dapat dikatakan berhasil dalam kategori sangat baik. Guru mampu mengatasi situasi yang mengganggu pada saat proses pembelajaran. 
4) Refleksi

Berdasrkan analisis hasil observasi yang telah dilakukan selama siklus II, terlihat bahwa proses pembelajaran terlaksana dengan lebih baik dan kondusif, baik itu dari segi aktivitas belajar siswa ataupun guru dengan kategori sangat tinggi dan sangat baik.

\section{DISKUSI}

Penelitian dilakukan untuk meningkatkan aktivitas belajar siswa melalui penggunaan alat peraga dalam materi operasi dalam pecahan. Pembelajaran dilaksanakan dengan penekanan pada keaktifan dan keterampilan siswa dalam menggunakan alat peraga sebagai sarana untuk memahami konsep.

\section{Ringkasan Hasil Aktivitas Belajar Siswa Siklus I dan Siklus II}

\begin{tabular}{|l|l|l|l|l|}
\hline & SIKLUS I & Kategori & SIKLUS II & Kategori \\
\hline Pertemuan I & 12,32 & Cukup & 17,67 & Tinggi \\
\hline Pertemuan II & 13,66 & Cukup & 21 & Sangat Tinggi \\
\hline $\begin{array}{l}\text { Persentase } \\
\text { Peningkatan }\end{array}$ & $1,34 \%$ & $3,33 \%$ & \\
\hline
\end{tabular}

Berdasarkan hasil aktivitas diatas terlihat bahwa terjadi peningkatan aktivitas belajar siswa dengan persentase pada siklus I sebesar 1,34\% dan siklus II 3,33\%. Dengan demikian aktivitas belajar siswa secara umum mengalami kenaikan/peningkatan dengan persentase 1,99\%. Dari kategori Cukup pada Siklus I menjadi kategori Sangat Tinggi setelah dilaksanakan siklus II.

Hasil penelitian menunjukkan bahwa keterampilan berhitung dengan menggunakan alat peraga dapat menumbuhkan suasana pembelajaran yang berorientasi pada keaktifan siswa, dimulai dari menemukan konsep sendiri melalui alat peraga dilanjutkan dengan perhitungan pecahan dengan operasi penjumlahan dan pengurangan. Secara keseluruhan, penggunaan alat peraga ini efektif dalam meningkatkan aktivitas belajar siswa. Hal ini sejalan dengan pendapat ${ }^{3}$ Faizal [2010] alat peraga merupakan instrument audio maupun visual yang digunakan untuk

${ }^{4}$ Faizal. 2010 dalam http:// nawawielfatru.blogspot.com/2009/05/keaktifanbelajar. Diakses tanggal 7 Januari 2020 
membantu proses pembelajaran menjadi lebih menarik \& membangkitkan minat siswa dalam mendalami suatu materi. Sementara itu ${ }^{4}$ Sudjana (2009) mendefinisikan alat peraga sebagai suatu alat yang dapat diserap oleh mata \& telinga dengan tujuan membantu guru agar proses belajar mengajar siswa lebih efektif \& efisien.

Hasil penelitian ini juga didukung oleh beberapa penelitian yang telah dilakukan sebelumnya, yaitu ${ }^{5}$ Etika (2016) melakukan penelitian tentang penggunaan alat peraga dalam meingkatkan aktivitas dan hasil belajar siswa pada mata pelajaran matematika dan hasilnya menunjukkan bahwa aktivitas siswa siklus I cukup aktifdan pada siklus II menjadi aktif. Demikian juga hasil belajarsiswa siklus I dengan kategori baik dan siklus II mengalami peningkatan dengan kategori sangat baik. Selain itu ${ }^{6}$ Suprayanti, Ayub dan Rahayu (2016) dalam artikelnya yang berjudul Penerapan Model Discovery Learning Berbantuan Alat Peraga Sederhana untuk Meningkatkan Aktivitas dan Hasil Belajar Siswa menyatakan bahwa hasil belajar dan aktivitas belajar siswa serta skor aktivitas guru mengalami peningkatan dari siklus I ke siklus II. Dengan demikian, penerapan model Discovery Learning berbantuan alat peraga sederhana dapat digunakan sebagai alternatif pembelajaran untuk meningkatkan aktivitas dan hasil belajar

Ringkasan Hasil Aktivitas Guru Siklus I dan Siklus II

\begin{tabular}{|l|l|l|l|l|}
\hline & SIKLUS I & Kategori & SIKLUS II & Kategori \\
\hline Pertemuan I & 3,67 & Baik & 4 & Baik \\
\hline Pertemuan II & 3,83 & Baik & 4,17 & Sangat Baik \\
\hline $\begin{array}{l}\text { Persentase } \\
\text { Peningkatan }\end{array}$ & $0,16 \%$ & $0,17 \%$ & \\
\hline
\end{tabular}

\footnotetext{
${ }^{5}$ Nana Sudjana. 2009. Penilaian Hasil Proses Belajar Mengajar. Bandung: PT Remaja Rosdakarya ${ }^{6}$ Etika Resmiyati. 2016. "Penggunaan Alat Peraga Untuk Meningkatkean Aktivitas dan Hasil Belajar Siswa Pada Pelajaran Matematika Kelas IV SD Negeri 9 Metro Pusat Tahun Pelajaran 2015/2016”. Skripsi Universitas Lampung Bandar Lampung, http:/ / digilib.unila.ac.id/24982/3/SKRIPSI\%20TANPA\%20BAB\%20PEMBAHASAN.pdf ${ }^{7}$ Suprayanti, Muh. Ayub \& Sri Rahayu. 2016. "Penerapan Model Discovery Learning Berbantuan Alat Peraga Sederhana untuk. Meningkatkan Aktivitas dan Hasil Belajar Siswa Kelas VII SMPN 5 Jonggat Tabun Pelajaran 2015/2016". Jurnal Pendidikan Fisika dan Teknologi (ISSN. 2407-6902) Volume II No 1, Halaman 30-35. Diakses tanggal: 4 Januari 2020.
} 
Berdasarkan hasil aktivitas diatas terlihat bahwa terjadi peningkatan aktivitas guru walaupun tidak signifikan dengan persentase pada siklus I sebesar 0,16\% dan siklus II $0,17 \%$. Dengan demikian aktivitas belajar siswa secara umum mengalami kenaikan/peningkatan dengan persentase 0,01\%. Dari kategori Baik pada siklus I menjadi kategori Sangat Baik setelah pelaksanaan siklus II.

Hasil penelitian menunjukkan bahwa guru dapat lebih mengaktifkan siswa dalam kegiatan pembelajaran yaitu dengan cara memberi kesempatan pada siswa secara bergantian untuk maju mempraktekkan penggunaan alat peraga di depan kelas, memberikan motivasi pada siswa yang masih belum berani dan ragu-ragu dan memberikan bimbingan secara khusus bagi beberapa siswa yang masih kesulitan untuk menggunakan alat peraga baik pada saat jam pelajaran matematika di kelas ataupun diluar jam pelajaran.

\section{KESIMPULAN}

Berdasarkan hasil penelitian dan analisis data yang telah dilakukan maka dapat diambil kesimpulan bahwa penggunaan alat peraga dapat meningkatkan aktivitas belajar siswa dengan persentase pada siklus I sebesar 1,34\% dan siklus II 3,33\%. Dengan demikian aktivitas belajar siswa secara umum mengalami kenaikan/peningkatan dengan persentase 1,99\%. Dari kategori Cukup pada Siklus I menjadi kategori Sangat Tinggi setelah dilaksanakan siklus II.

\section{DAFTAR PUSTAKA}

Etika Resmiyati. 2016. "Penggunaan Alat Peraga Untuk Meningkatkan Aktivitas dan Hasil Belajar Siswa Pada Pelajaran Matematika Kelas IV SD Negeri 9 Metro Pusat Tahun Pelajaran 2015/2016". Skripsi Universitas Lampung Bandar Lampung, http://digilib.unila.ac.id/24982/3/SKRIPSI\%20TANPA\%20BAB\%20PEMB AHASAN.pdf

Faizal. 2010 dalam http:// nawawielfatru.blogspot.com/2009/05/keaktifanbelajar

Moleong, Lexy J. 2010. Metodologi Penelitian Kualitatif. Bandung: Remaja Rosdakarya.

Mustaqim, Burhan. Ayu belajar matematika. Jakarta. Depatemen Pendidikan.

Nana Sudjana. 2009. Penilaian Hasil Proses Belajar Mengajar. Bandung: PT Remaja Rosdakarya 
Baiq Yuni Wahyuningsih

Suprayanti, Ayub \& Rahayu. 2016. "Penerapan Model Discovery Learning Berbantuan Alat Peraga Sederhana untuk. Meningkatkan Aktivitas dan Hasil Belajar Siswa Kelas VII SMPN 5 Jonggat Tabun Pelajaran 2015/2016". Jurnal Pendidikan Fisika dan Teknologi (ISSN. 2407-6902) Volume II No 1, Halaman 30-35.

Wibowo Ari. Confusius. https://gendhonzz.wordpress.com/confusius/ diakses tanggal 5 Januari 2020. 